\title{
Performance Analysis of Ripv2, OSPF and EIGRP Protocols using Cisco Packet Tracer Simulator 7.2
}

\author{
Murali Krishna M, Prasantha R. Mudimela, Pitcheri Praveen Kumar
}

\begin{abstract}
Figured out in modern massive networks there are existing of many independent system, vibrant transmitting procedures implemented regularly than the different kinds of fixed routing protocol, by the application of various new sorts of directing procedures can efficiently services the contemporary large system in the networking. The contemporary design of different transmitting convention protocols must be taken into considerations of current and as well as services need to be applied in the future by considering this for today's scenario witnessing a great development adjustment in the web traffic that is generated by utilization of the various applications. This study was conducted to test the performance analysis in between RIPV2, OSPF and also EIGRP with cisco package tracer simulator 7.2.
\end{abstract}

Search phrases- DNS, EIGRP, HTTP, HTTPS, RTP, Routing protocols

\section{INTRODUCTION}

Indeed, beginning from production of the first PCs, the need for interconnection turned into a noteworthy enthusiasm for solicitation to part the outcomes acquired after the execution of various tasks they were at first expected for. As the time progressed by, a great deal of the makers started to build up their very own uncommon structures of interconnections for their PCs. This interconnections problem was major concern between the clients this issue was as yet incapable to be comprehended because of the assorted conventions that were utilized so as to intercommunicate in different geological zones. Exactly when this first concern was unwound at the same time appeared in the essential minimal size of veritable frameworks, which are referred to later on as the Local area networks (LAN). As the number of computer systems boost and various other kind of devices (such as IP interaction cell phones, printers, and also various other smart devices which were developed to establish the interaction), was created the following phase, which is recognized as Metropolitan area networks. The Wide Area Network (WAN) in correlation with the MAN systems is not topographically restricted. The critical advantage that these systems are that it tends to have the option to interface with much more assortments of Local area networks.

Revised Manuscript Received on February 05, 2020.

* Correspondence Author

Murali Krishna M, School of Electronics \& Electrical Engineering (SEEE), Lovely Professional University, Phagwara, Punjab, India

Prasantha R. Mudimela, School of Electronics \& Electrical Engineering (SEEE), Lovely Professional University, Phagwara, Punjab, India

Pitcheri Praveen Kumar, Department of Electronics and Communications Engineering, Anurag Group of Institutions, Hyderabad, India

(C) The Authors. Published by Blue Eyes Intelligence Engineering and Sciences Publication (BEIESP). This is an open access article under the CC BY-NC-ND license (http://creativecommons.org/licenses/by-nc-nd/4.0/)
At the time being the execution of PC systems offer us the chance to make an interface and furthermore to take part in veritable time systems. Right now, we utilize these all systems at most extreme sum ability so as to use an extraordinary scope of utilizations, for example, holding fast to: web applications, video gatherings, web based business applications, on the web papers applications, video chat online papers applications and a lot more applications

As the significantly fast advancement of the brandnew innovation, the development in creating of an interchanges system is moreover getting greater and furthermore greater. In contemporary correspondence systems in the Internet, the dynamic routing method are made use of rather than fixed types routing method. With the growth of the network, we need a vibrant sort of transmitting procedure design that can suit all these modifications without treatment of the executive when a changing or building up a particular system. Some coordinating protocol [1] used to make the AS (Autonomous System) called as the execution Interior Gateway Protocol. The independent system application using these protocols can trade the details openly with in the Autonomous System.

With respect to the delivering protocol that is executed to interface the AS in enormous sorts of the systems is called Exterior PCs, the interest of their intercommunication turned into a noteworthy in order to share the relating results got after the execution of different issues they were from the outset designed. As the time advanced by, a section of the producers started to make their own one of a kind remarkable new sort of frameworks for the intercommunication for their PC structures. Afterwards, although the necessity of intercommunication ended up being a huge issue among the clients, this issue was now unfit to be settled in light of the different frameworks that were utilized in order to intercommunicate in different geological zones.

\section{ASSOCIATED WORK}

Routing methods need to be effectively planned and to be dimensioned for each kind of the network. This transmitting protocol execution can be done according to the demand of the network manager. The main benefit of these transmitting procedures includes the truth that they are merge extremely rapidly, even if the major path is stated to be disappears in the network, implying that these protocols are consequently overhauled or versatile themselves [1] 
So as to improve the exhibition of transmitting protocols, the style execution must be in all respects deliberately chosen all together not to over-burden the diminished proficiency equipment. The efficient transmitting techniques are additionally divided into two arrangements: 1. Indoor routing methodology and 2 . Outside transmitting methodology.

The RIPng method uses the range vector formulas for determining the best course in a provided network. While OSPFv3 directing technique utilizes the web connection state calculation to make sense of the absolute best way in a given system. While EIGRP uses a distance vector in along with link state. The implementation RIPng is done for making use of medium-scale Network down to the assortment of hosts that are professed to be not very enormous. The OSPFv3 routing method appropriate for use on a network tool ranges as much as an extension of multiple numbers of hosts. EIGRP can also be an appropriate solution for executing in large-scale networks, yet it can be just being applied in EIGRP router cisco.

To the classification "Distance vector" belongs the complying with procedures: RIP variation 1, RIP version 2, OSPF as well as EIGRP [2-6] these protocols are defined by the complying with functions as below revealed:

- Algorithms can be applied easily, and incredibly simple to be determined by the $\mathrm{cpu}$;

- They don't tire the system with a major measure of system math;

- They don't have a picture of framework topology;

- They are scaled on little frameworks just as they additionally have verification;

- One of the best issues of these directing techniques is the coordinating escape clauses.

If in a router more than one routing method is carried out, the one which has fastest distance which can be taking into consideration as top priority. As an example, a transmitting protocol carried out in router is using OSPF method and also EIGRP protocol, in this instance the EIGRP protocol will certainly be utilized to course the data plans the reason is that the EIGRP protocol administrative range shorter compare to the OSPF, respectively 90 contrasting to 120 [2].

\section{PERFORMANCE ANALYSIS OF THE ROUTING USING CISCO PACKET TRACER}

Packet Tracer is an innovative and powerful networking simulation tool used for practice, discovery and troubleshooting. is a simulation programming application made by Cisco firm so as to repeat the different devices and likewise numerous methods that are utilized for devices interconnection in order to carry out the networks; they can be examined in what concerns their feature to avoid the concerns that might take place [7-9]

It is possible to do, as an example, the various routers supplied by Cisco Packet Tracer, main difference to consider when placing the tool in the simulations are the potentially hardware limitations that are including the devices, in terms of variety of ports available, options to alter the network interfaces, number of expansion slot and so on. A considerable listing of button, laptop computer, server and computer is also readily available in the tool.

Utilizing Packet Tracer mimicing programming we have created and evaluated the demonstrated system that we furthermore partitioned into 6 regions from figure- 2 to fihure-7. In this the basic zone named as Floor Level 0 and we set a few workstations (workstation 11, 12, 13, 14, 15, $16,17,18,19--$ with first stage pupils, Server 3 very beginning) automated IP addresses can be obtained making use of DHCP from network. A cordless router and also server 3 first stage allocate IPs in system 192.168.0.0/29 utilizing the execution of DHCP. The smart devices such as tablet as well as the mobiles are linked to the the Wi-Fi switch as shown in figure-1.

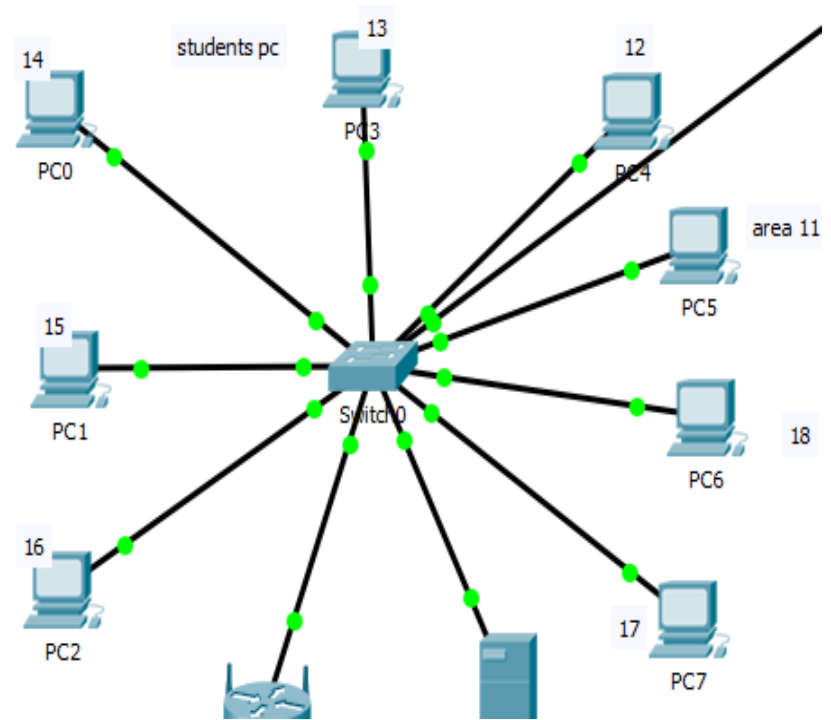

Figure-1. Implementation setup at the

Floor Level 0 area

In second location, the name is given as First Floor; with implementation of 4 virtual local area networks (VLAN) as well as matching names were assigned per VLAN as Teachers/Instructors, Students, Voice as well as Management. The networks which are assigned to equivalent 4 VLANS has specified the complying with networks: for Students - 172.16.1.0/24, for Teachers/Instructors-172.16.2.0/24, for Voice 172.16.3.0/24 as described in (Figure 2).

In the $3^{\text {rd }}$ area the name is provided as Second Floor as well as here likewise we have produced 4 online lan (VLANs) and also corresponding names were designated per VLAN as Students, Teachers/Instructors, Voice and Management. The networks which are designated to corresponding 4 VLANS has specified the adhering to networks: for Students - 172.16.1.0/ 24, for Teachers 172.16.2.0/ 24, for Voice - 172.16.3.0/24. Below the entire tool obtain automated IP addresses utilizing DHCP application from the router R4 as received listed below (Figure 3). 
Corresponding names were assigned to every VLAN as Teachers/Instructors, Students, Voice as well as Management. The networks which are designated to corresponding 4 VLANS has actually defined by the given networks: for Students - 172.16.1.0, for Teachers/ Instructors- 172.16.2.0, for Voice - 172.16.3.0 and also for Management -172.16.90.0. Besides the workstations, we additionally implemented around a web internet browser server with a static IP address of 172.16.2.2/ 24 expressed in the server so as to arrive at the site given and also the site can be reached kind of smart device from different network in the communication as received (Figure 4).

In the fifth area the name is provided as Home. In house zone we can discover a web server, which is offering access to the distinctive kind of devices and the devices $\mathrm{s}$ are: Store room, Webcam, Central warming and Air Condition. All these gadgets have actually designated with a

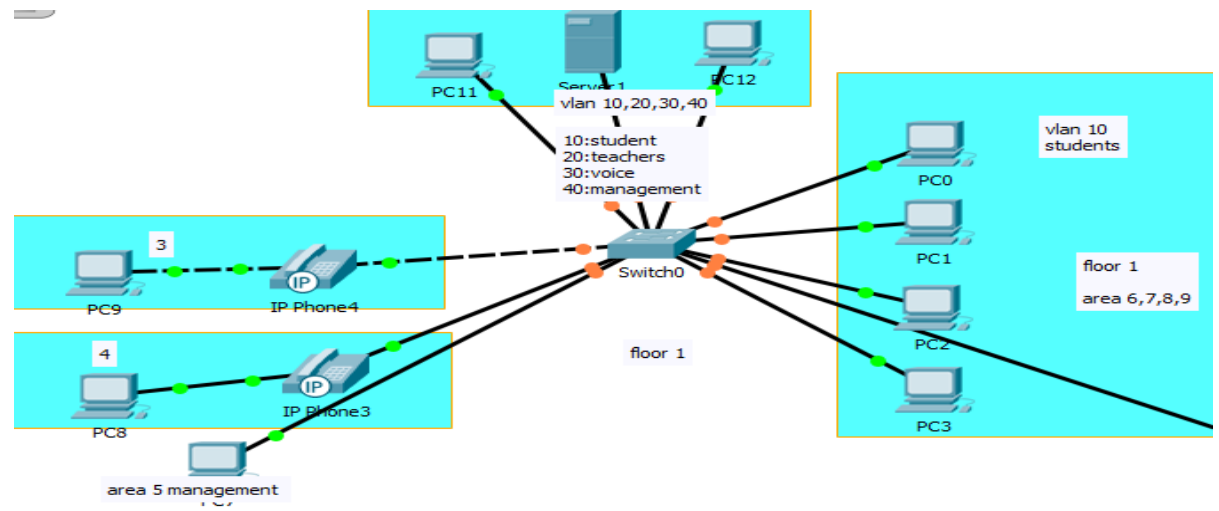

Figure-2. Floor Level 1 Implementation

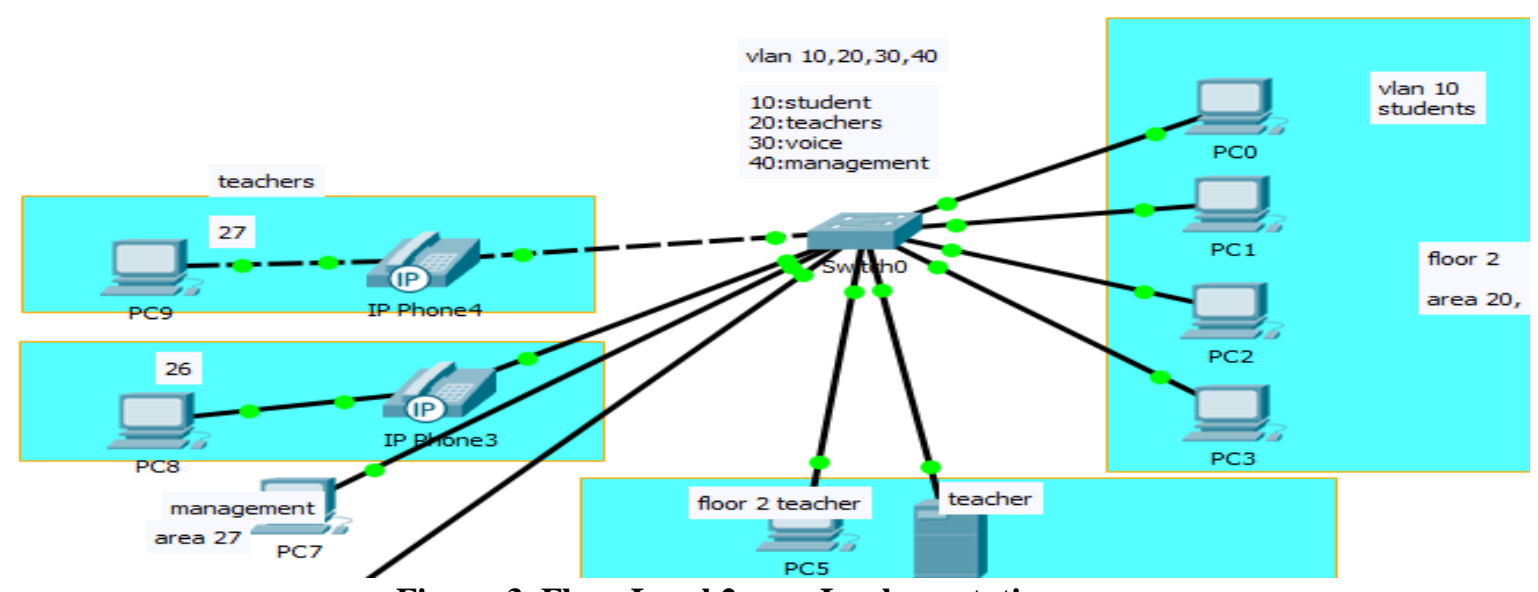

Figure-3. Floor Level 2 area Implementation

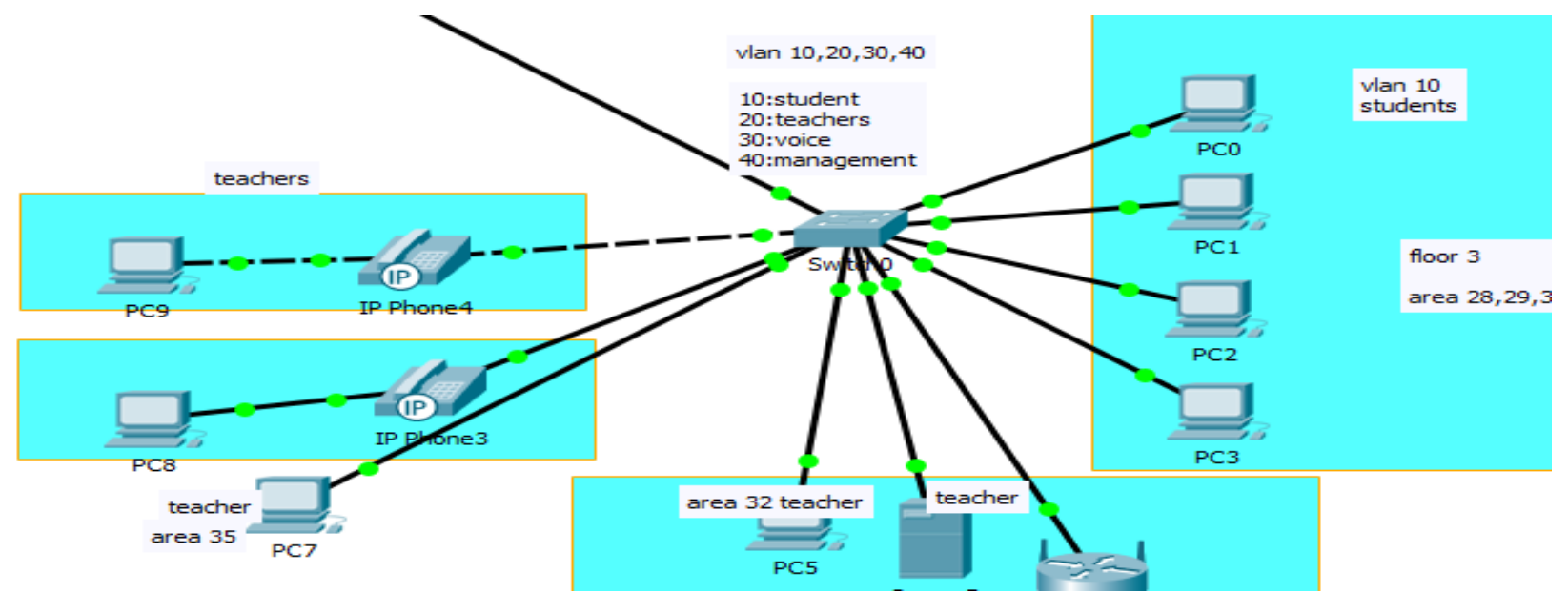

Figure-4. Floor Level 3 area Implementation

Published By:

Blue Eyes Intelligence Engineering

\& Sciences Publication 
In the fourth area we have actually developed 4 online local area networks (VLANs).

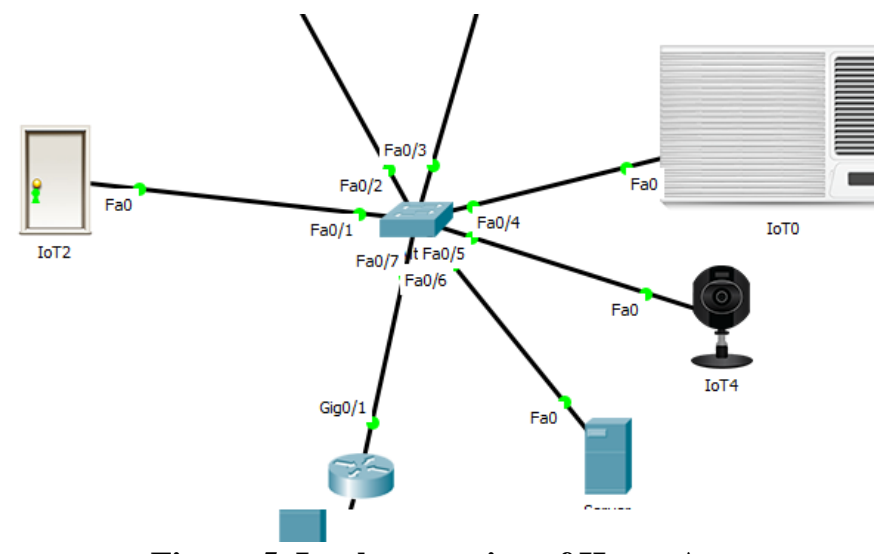

Figure-5. Implementation of Home Area

We likewise produced the Servers space which is the Sixth Area, which is responsible for offering the assortment of use in the system, for example, Electronic MAIL, FTP, HTTP, NTP, DNS and SERVER 3G. All these have actually repaired IP address which is designated from network 172.16.1.0/24 shown below (Figure 6).

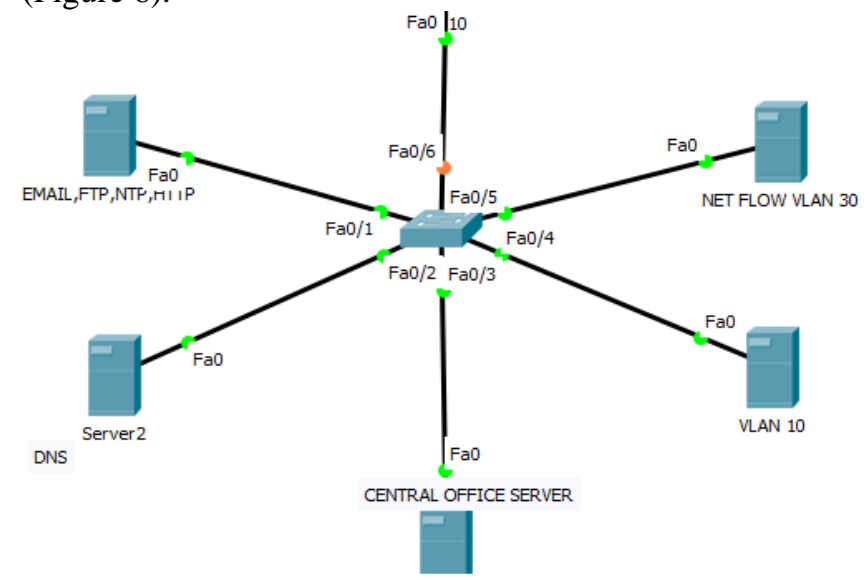

Figure-6. Implementation of Servers Area

At that point we furthermore executed the seventh area which contain 2 tablets and furthermore 4 advanced mobile phones which get the IPs from $3 G$ and Wi-Fi systems. 2 Smart phones with 0 and 1 are attached to WANs from the cordless router carried out in Floor level zero Area by which they are additionally attached to the 3G network. Two Smart telephones with number 2 and 3 are associated with the remote switch which lies in the Floor level 3 Area and furthermore 3G networks. The exceptionally identical scenarios utilized with tablets 0 and 1 by methods for $\mathrm{Wi}-\mathrm{Fi}$ from the two switches and $3 \mathrm{G}$ from the work station.

A. EIGRP network performance evaluation First Scenario-In this situation EIGRP routing method is configured on the all routers in the network area and The relating development time in the middle of the devices got for this circumstance, for the data occurrence HTTPS and also DNS services are shown up in Table I, for the states of RTP and furthermore HTTPS answers, are represented in Table II as appeared. From the simulation results as shown in Tables III For EIGRP protocol, may be settled by the followings: The utility of web server among the Floor Level 0 Students the pc 10 and for Teachers the Server 20 has affected the period in between these minute of the initialization of internet browser use the services of https and the time of the site page is stacked once in a while duration of $0.033 \mathrm{~ms}$ as shown

For http making use of the route from the Smartphone 2 to the corresponding Management Server as well as back to the Smart device (phone 2) we are getting the delay of $0.020 \mathrm{~ms}$ as shown.

By using the RTP service from smart phone 1 to the smart phone 3 we are obtaining hold-up of $0.007 \mathrm{~ms}$ as observed.

B. OSPF routing method network efficiency analysis Scenario 2--

In this scenario OSPF routing procedure is set up on the all routers in the network location as well as the coordinating activity time in the middle of the gadgets got for this condition, for the particular cases Hyper Text Transfer Protocol Secure Service and Domain Name System game plans are recorded in Table III as appeared, and furthermore for the circumstances of Hyper Text Transfer Protocol Secure Service and Real-Time Transport Protocol Service administrations, are represented in Table IV

C. OSPF - From the simulation results as shown in Tables III-IV for OSPF procedure, Can be discovered the followings: The getting to of net server between the Floor Level 0 Students (PC 10) and Teachers/Instructors (Server 20) has without a doubt affected the span time in the middle of those snapshot of the introduction of the program utilize the Hyper Text Transfer Protocol Secure arrangement. In addition to the moment of the net page is loaded every now and then period of $0.033 \mathrm{~ms}$ as observed.

For http making use of the route from the Smart device phone 2 to the Relating Management Server and moreover came back to the Smart device phone 2 we're acquiring put off of to $0.021 \mathrm{~ms}$ as demonstrated, by utilizing the service of RTP With the help of Phone 1 to the Phone 3 we have progressed toward becoming deferral of $0.006 \mathrm{~ms}$ as uncovered.

\section{RIPv2 directing protocol network efficiency Scenario} 3--

E. RIPv2- In this condition RIPv2 steering methodology is designed on the all switches in the system area and furthermore the relating activity time between the apparatuses got for this situation, for the details instances Hyper Text Transfer Protocol Secure as well as Domain Name System solutions are given up Table V as uncovered, and for the instances of administrations, for example, RealTime Transport Protocol and Hyper Text Transfer Protocol Secure, are shown in Table VI.

F. From the simulation results as displayed in Tables V-VI for RIPV2 method, can be comprehended the followings:

- The gaining access to of internet server among the Floor Level 0 Students( pc 10) as well as Teachers (Server 20) has surely encouraged the duration time among these minute of the instatement of the net browser which use the Hyper Text Transfer Protocol Secure service as well as the minute of the internet site is packed once in a duration of $0.340 \mathrm{~ms}$;

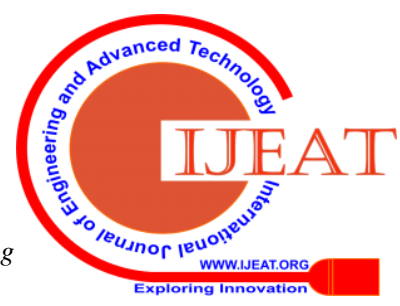


- For http utilizing the course from the Smart device-phone 2 to the corresponding Server and returned to the Smart device-phone 2 we are becoming hold-up of zero $0.023 \mathrm{~ms}$;

\section{RESULTS AND DISCUSSIONS}

The obtained simulation results are tabulated. Table I to IV shows the response time of the protocols of EIGRP, OSPF, RIPv2 implementations.

Table I. Response Time by using EIGRP (DNS, HTTPS)

\begin{tabular}{|c|l|c|l|}
\hline \multicolumn{4}{|c|}{ EIGRP Protocol (First Scenario) } \\
\hline $\begin{array}{c}\text { Time } \\
\text { (ms) }\end{array}$ & $\begin{array}{l}\text { Domain Name } \\
\text { System } \\
\text { Service }\end{array}$ & $\begin{array}{c}\text { Time } \\
\text { (ms) }\end{array}$ & $\begin{array}{c}\text { Hyper Text } \\
\text { Transfer Protocol } \\
\text { Secure Service }\end{array}$ \\
\hline 0 & $\begin{array}{l}\text { WorkStation } \\
10\end{array}$ & 0.020 & WorkStation 10 \\
\hline 0.001 & $\begin{array}{l}\text { Switch at Floor } \\
\text { Level 0 }\end{array}$ & $\begin{array}{c}0.02 \\
4\end{array}$ & $\begin{array}{l}\text { Switch at Floor } \\
\text { Level 0 }\end{array}$ \\
\hline 0.002 & R2 & 0.025 & R2 \\
\hline 0.003 & R3 & 0.026 & R1 \\
\hline 0.004 & $\begin{array}{l}\text { Servers Room } \\
\text { switch }\end{array}$ & 0.027 & R4 \\
\hline 0.005 & $\begin{array}{l}\text { Domain Name } \\
\text { Server }\end{array}$ & 0.028 & $\begin{array}{l}\text { Switch at Floor } \\
\text { Level 3 }\end{array}$ \\
\hline 0.006 & $\begin{array}{l}\text { Servers Room } \\
\text { switch }\end{array}$ & 0.02 & Server 20 Teachers \\
\hline 0.007 & R3 & 0.03 & $\begin{array}{l}\text { Switch at Floor } \\
\text { Level 3 }\end{array}$ \\
\hline 0.008 & R2 & 0.030 & R4 \\
\hline 0.009 & $\begin{array}{l}\text { Switch at Floor } \\
\text { Level 0 }\end{array}$ & 0.03 \\
R1 \\
\hline 0.01 & $\begin{array}{l}\text { WorkStation } \\
10\end{array}$ & 0.033 & WorkStation 10 \\
\hline
\end{tabular}

Table II. Response Time of by using EIGRP (HTTP, RTP)

\begin{tabular}{|c|c|c|c|}
\hline \multicolumn{4}{|c|}{ EIGRP Protocol (First Scenario) } \\
\hline $\begin{array}{c}\text { Tim } \\
\text { (ms) }\end{array}$ & $\begin{array}{l}\text { Hyper Text } \\
\text { Transfer Protocol } \\
\text { Service }\end{array}$ & $\begin{array}{c}\text { Tim } \\
\text { e } \\
(\mathrm{ms})\end{array}$ & $\begin{array}{l}\text { Real-Time } \\
\text { Transport } \\
\text { Protocol Service }\end{array}$ \\
\hline 0 & $\begin{array}{l}\text { Smart device phone } \\
2\end{array}$ & 0 & $\begin{array}{l}\text { Smart device- } \\
\text { phone } 1\end{array}$ \\
\hline $\begin{array}{c}0.00 \\
1\end{array}$ & $\begin{array}{l}\text { Wireless router } \\
0\end{array}$ & $\begin{array}{c}0.00 \\
1\end{array}$ & $\begin{array}{l}\text { Switch at Floor } \\
\text { Level } 1\end{array}$ \\
\hline $\begin{array}{c}0.00 \\
2\end{array}$ & $\begin{array}{l}\text { Switch at Floor } \\
\text { Level } 3\end{array}$ & $\begin{array}{c}0.00 \\
2\end{array}$ & $\mathrm{R} 2$ \\
\hline $\begin{array}{c}0.00 \\
3\end{array}$ & R4 & $\begin{array}{c}0.00 \\
3\end{array}$ & R3 \\
\hline $\begin{array}{c}0.00 \\
4\end{array}$ & R1 & $\begin{array}{c}0.00 \\
4\end{array}$ & $\mathrm{R} 4$ \\
\hline $\begin{array}{c}0.00 \\
5\end{array}$ & Home Router & $\begin{array}{c}0.00 \\
5\end{array}$ & $\begin{array}{l}\text { Switch at Floor } \\
\text { Level } 2\end{array}$ \\
\hline $\begin{array}{c}0.00 \\
6\end{array}$ & Home Switch & $\begin{array}{c}0.00 \\
6\end{array}$ & $\begin{array}{l}\text { Smart device- } \\
\text { phone } 3\end{array}$ \\
\hline
\end{tabular}

Table III. Response Time using OSPF (DNS, HTTPS)

\begin{tabular}{|c|c|c|c|}
\hline \multicolumn{4}{|c|}{ OSPF Protocol (The Second Scenario) } \\
\hline $\begin{array}{l}\text { Time } \\
\text { (ms) }\end{array}$ & $\begin{array}{l}\text { Domain Name } \\
\text { System Service }\end{array}$ & $\begin{array}{r}\text { Time } \\
\text { (ms) }\end{array}$ & \begin{tabular}{|l|} 
Hyper Text \\
Transfer Protocol \\
secured Service
\end{tabular} \\
\hline 0 & Workstation 10 & 0.022 & Workstation 10 \\
\hline $\begin{array}{c}0.00 \\
1\end{array}$ & $\begin{array}{l}\text { Switch at Floor } \\
\text { Level } 0\end{array}$ & 0.023 & $\begin{array}{l}\text { Switch at Floor } \\
\text { Level } 0\end{array}$ \\
\hline $\begin{array}{c}0.00 \\
2\end{array}$ & $\mathrm{R} 2$ & 0.024 & $\mathrm{R} 2$ \\
\hline $\begin{array}{c}0.00 \\
3\end{array}$ & R3 & 0.024 & R1 \\
\hline $\begin{array}{c}0.00 \\
4\end{array}$ & $\begin{array}{l}\text { Switch at } \\
\text { Servers Room }\end{array}$ & 0.025 & R4 \\
\hline $\begin{array}{c}0.00 \\
5 \\
\end{array}$ & $\begin{array}{l}\text { Domain Name } \\
\text { Server }\end{array}$ & 0.026 & $\begin{array}{l}\text { Switch at Floor } \\
\text { Level } 3\end{array}$ \\
\hline $\begin{array}{c}0.00 \\
6\end{array}$ & $\begin{array}{l}\text { Switch at } \\
\text { Servers Room }\end{array}$ & 0.027 & $\begin{array}{l}\text { Teachers Server } \\
5\end{array}$ \\
\hline $\begin{array}{c}0.00 \\
7\end{array}$ & R3 & 0.03 & $\begin{array}{l}\text { Switch at Floor } \\
\text { Level } 3\end{array}$ \\
\hline $\begin{array}{c}0.00 \\
8\end{array}$ & $\mathrm{R} 2$ & 0.028 & R4 \\
\hline $\begin{array}{c}0.00 \\
9\end{array}$ & $\begin{array}{l}\text { Switch at Floor } \\
\text { Level } 0\end{array}$ & 0.030 & R1 \\
\hline
\end{tabular}

Table IV. Response Time of OSPF (HTTP, RTP)

\begin{tabular}{|c|c|c|c|}
\hline \multicolumn{4}{|c|}{ EIGRP Protocol (The Second Scenario) } \\
\hline $\begin{array}{l}\text { Time } \\
\text { (ms) }\end{array}$ & $\begin{array}{l}\text { Hyper Text } \\
\text { Transfer } \\
\text { Protocol Service }\end{array}$ & $\begin{array}{l}\text { Time } \\
\text { (ms) }\end{array}$ & $\begin{array}{l}\text { Real-Time } \\
\text { Transport } \\
\text { Protocol } \\
\text { Service }\end{array}$ \\
\hline 0 & $\begin{array}{l}\text { Smart Device- } \\
\text { phone } 2\end{array}$ & 0 & $\begin{array}{l}\text { Smart device- } \\
\text { Phone } 1\end{array}$ \\
\hline 0.004 & $\begin{array}{l}\text { Wireless } \\
\text { Router R0 }\end{array}$ & 0.001 & $\begin{array}{l}\text { Switch at Floor } \\
\text { Level } 1\end{array}$ \\
\hline 0.005 & $\begin{array}{l}\text { Switch at } \\
\text { Floor Level } 3\end{array}$ & 0.002 & $\mathrm{R} 2$ \\
\hline 0.006 & R4 & 0.003 & R3 \\
\hline 0.007 & R1 & 0.004 & $\mathrm{R} 4$ \\
\hline 0.008 & Router Home & $\begin{array}{c}0.00 \\
5\end{array}$ & $\begin{array}{l}\text { Switch at Floor } \\
\text { Level } 2\end{array}$ \\
\hline 0.009 & Home switch & 0.006 & $\begin{array}{l}\text { Smart device- } \\
\text { Phone } 3\end{array}$ \\
\hline 0.01 & Server 1 & & \\
\hline 0.012 & Home switch & & \\
\hline 0.013 & Home router & & \\
\hline 0.014 & R1 & & \\
\hline 0.015 & R4 & & \\
\hline 0.016 & $\begin{array}{l}\text { Switch at } \\
\text { Floor Level } 3\end{array}$ & & \\
\hline 0.017 & $\begin{array}{l}\text { Wireless } \\
\text { router R0 }\end{array}$ & & \\
\hline 0.022 & $\begin{array}{l}\text { Smart device- } \\
\text { phone } 2\end{array}$ & & \\
\hline
\end{tabular}


Table V. Response Time of RIPv2 (DNS, HTTPS) OSPF Protocol (The Third Scenario)

\begin{tabular}{|c|l|c|l|}
\hline $\begin{array}{c}\text { Time } \\
\text { (ms) }\end{array}$ & $\begin{array}{l}\text { Domain Name } \\
\text { System } \\
\text { Service }\end{array}$ & $\begin{array}{c}\text { Time } \\
\text { (ms) }\end{array}$ & $\begin{array}{l}\text { Hyper Text } \\
\text { Transfer Protocol } \\
\text { secured Service }\end{array}$ \\
\hline 0.004 & workstation 10 & 0.329 & workstation 10 \\
\hline 0.005 & $\begin{array}{l}\text { Switch at } \\
\text { Floor Level 0 }\end{array}$ & 0.330 & $\begin{array}{l}\text { Switch at Floor } \\
\text { Level 0 }\end{array}$ \\
\hline 0.006 & R2 & 0.331 & R2 \\
\hline 0.007 & R3 & 0.332 & R1 \\
\hline 0.008 & $\begin{array}{l}\text { Switch at } \\
\text { Servers Room }\end{array}$ & 0.333 & R4 \\
\hline 0.009 & $\begin{array}{l}\text { Domain Name } \\
\text { Server }\end{array}$ & 0.334 & $\begin{array}{l}\text { Switch at Floor } \\
\text { Level 3 }\end{array}$ \\
\hline 0.01 & $\begin{array}{l}\text { Switch at } \\
\text { Servers Room }\end{array}$ & 0.335 & $\begin{array}{l}\text { Server 5 } \\
\text { Teachers/ }\end{array}$ \\
\hline 0.011 & R3 & 0.336 & $\begin{array}{l}\text { Switch at Floor } \\
\text { Level 3 }\end{array}$ \\
\hline 0.012 & R2 & 0.337 & R3 \\
\hline 0.013 & workstation 10 & 0.38 & R2 \\
\hline 0.014 & workstation 10 & 0.339 & workstation 10 \\
\hline
\end{tabular}

Table VI. Response Time of RIPv2 (HTTP, RTP)

\begin{tabular}{|c|c|c|c|}
\hline \multicolumn{4}{|c|}{ EIGRP Protocol (The Third Scenario) } \\
\hline $\begin{array}{r}\text { Time } \\
(\mathrm{ms})\end{array}$ & $\begin{array}{c}\text { Hyper Text } \\
\text { Transfer } \\
\text { Protocol } \\
\text { Service }\end{array}$ & $\begin{array}{r}\text { Time } \\
(\mathrm{ms})\end{array}$ & \begin{tabular}{|l|} 
Real-Time \\
Transport \\
Protocol \\
Service
\end{tabular} \\
\hline 0.005 & $\begin{array}{l}\text { Smart device- } \\
\text { phone } 2\end{array}$ & 0.026 & Phone 1 \\
\hline 0.006 & $\begin{array}{l}\text { Wireless } \\
\text { router } 0\end{array}$ & 0.027 & $\begin{array}{l}\text { Switch at Floor } \\
\text { Level } 1\end{array}$ \\
\hline 0.007 & $\begin{array}{l}\text { Switch at } \\
\text { Floor Level } 3\end{array}$ & 0.028 & $\mathrm{R} 2$ \\
\hline 0.008 & R4 & 0.03 & R3 \\
\hline 0.009 & R1 & 0.031 & $\mathrm{R} 4$ \\
\hline 0.01 & Home Router & 0.032 & Switch Level 2 \\
\hline 0.011 & Home Switch & 0.033 & $\begin{array}{l}\text { Smart device- } \\
\text { Phone } 3\end{array}$ \\
\hline 0.016 & R1 & & \\
\hline 0.017 & R4 & & \\
\hline 0.018 & $\begin{array}{l}\text { Switch at } \\
\text { Floor Level } 3\end{array}$ & & \\
\hline 0.019 & $\begin{array}{l}\text { Wireless } \\
\text { Router } 0\end{array}$ & & \\
\hline 0.022 & $\begin{array}{l}\text { Smart device } \\
\text { phone } 2\end{array}$ & & \\
\hline
\end{tabular}

\section{CONCLUSIONS}

After performing the simulation utilizing Cisco packet tracer for the different routing methods we can conclude that the EIGRP is the most effective protocol contrasted to OSPF as well as RIPV2 because of its much less issue formula compared to various other algorithm the one OSPF does; this set is all around very much scaled on the evaluated frameworks and moreover on the tremendous estimated frameworks, while OSPF convention is scaled both on the medium estimated and besides enormous estimated frameworks, the last computing the quickest way.
The table gives promoting and showcasing to the different switches in the system requesting an enormous sources and furthermore more expensive rate contrasting with EIGRP. From the simulation results we have gained response time of each coordinating technique just as we reason that the there are contrasts in the middle of these 3 protocols. These refinements are gotten by the calculations that present the hold-ups in the execution of certain administrations. We think about that Cisco packet tracer simulator tool provide us to apply and to mirror virtual systems and by utilizing these it can be prepared to get a web traffic decongestion, simultaneously we can reinforce the system wellbeing in like manner.

The significant benefit that these networks are that it can be able to connect with even more number of Local location networks. In current communication systems, for example, the Internet organize, dynamic steering technique is utilized as opposed to fixed sorts coordinating strategy. In this the initial area named as Floor Level 0 and also we inserted a multiple workstations (workstation 11, 12, 13, 14, 15, 16, 17, 18, 19-- with Floor level 0 pupils, Server 3 Level 0) automatic IP addresses can be gotten making use of DHCP from network on router 2, a cordless router and also web server 3 Level 0 allots IPs in system 192.168.0.0/ 29 using the execution of DHCP. 2 Smart device phones ( 0 and 1 ) are linked to cordless system have allotted IPs from the remote switch executed in Floor Level 0 Area as they are also connected to the 3G organize. We mull over that Cisco packet tracer test system programming application enables us to apply and furthermore to mimic virtual systems and furthermore by utilizing them we can ready to get a traffic decongestion, at correctly a similar time we can sustain the framework security.

\section{REFERENCES}

1. A. Bahnasse, \& N. Elkamoun, "Study and Analysis of a Dynamic Routing Protocols' Scalability over a Dynamic Multipoint Virtual Private Network", 2015.

2. C.G. Dumitrache, G. Predusca, L.D. Circiumarescu, N. Angelescu, D.C. Puchianu "Comparative study of RIP, OSPF and EIGRP protocols using Cisco Packet Tracer" 2017 5th International Symposium on Electrical and Electronics Engineering (ISEEE), 11 December 2017

3. D. Xu, \& L. Trajkovi, "Performance Analysis of RIP, EIGRP, and OSPF using OPNET", 2013

4. Cisco Dynamic Multipoint VPN: "Simple and Secure Branch-toBranch Communications", 2008.

5. Yutaka Arai, Eiji Oki. A Fast-Convergence Scheme to Update Metrics without Loop in OSPF networks.2011 1st International Symposium on Access Spaces (ISAS). Pp 213-217, June 2011.

6. Megha Jayakumar, N. Ramya Shanti Rekha, B. Bharathi, "A comparative study on RIP and OSPF protocols," International Conference on Innovation in Information, Embedded and Communication Systems (ICIIECS), 19-20, pp.1-5, March 2015

7. Yang, Q. F., Shi, H. H., Zhu, “Analysis the Advantages and Packet Format of EIGRP”, Applied Mechanics and Materials, 336, 2464 2467, 2013.

8. Savage, D., Slice, D., Ng, J., Moore, S., \& White, R., "Enhanced Interior Gateway Routing Protocol" Internet Engineering Task Force, 2015.

9. P. Christian. RFC 3147 - Generic Routing Encapsulation over CLNS Networks. Nortel Networks, July 2001

10. Jesin A, Packet Tracer Network Simulator, Packt Publishing, 2014.

11. http://www.cisco.com/c/en/us/s upport.

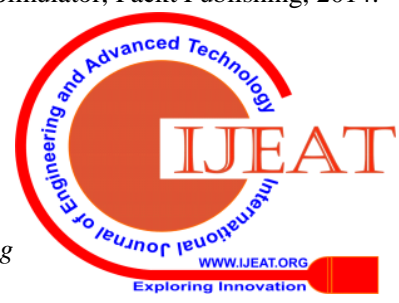

